\title{
TRENDS OF YIELDS ON THE INVESTMENTS OF FINANCIAL INSTITUTIONS*
}

\author{
JaMES J. O'LeARY $\uparrow$
}

The trend of yields on institutional investments has become a matter of considerable importance for an increasing number of people. The growth of institutional assets has been widely publicized in recent years, but little has been said about the ultimate ownership of this wealth. The fact is that the ownership of the resources of financial institutions becomes more widespread every year. There are now estimated to be some 83 million life insurance policyholders as compared with 64 million in 1938,53 million in 1927 , and only Io million in I900. There are nearly 15 million regular mutual savings bank accounts as compared with 12 million in 1938earlier data are not available. The increase in the number of savers and investors in savings and loan associations is even more impressive. The 1936 total was 4.3 million. By 1950 the total had increased to 10.7 million. Comparable figures on the ownership of commercial bank deposits apparently are not available, but these too have undoubtedly increased substantially in recent years.

This paper will first review the trend of yields on the investments of life insurance companies, commercial banks, mutual savings banks, and savings and loan associations, and then consider the implications of these trends in the light of the growth of institutional assets and their increasingly widespread ultimate ownership.

\section{Life Insurance Companies}

The net investment yield on life company funds is available from the Institute of Life Insurance from I9I5 to date. The high point in this series, 5.I8 per cent, was reached in r923, after which a persistent decline set in which lasted for more than 20 years. At the low point in 1947 , the net investment yield of the United States companies averaged only 2.88 per cent, slightly more than half of the yield earned in r923. The moderate recovery since 1947 still leaves the investment return at historically depressed levels. Table I shows the record from r915 through 1950 .

The decline in the rate of investment earnings from 1923 through 1947 , particularly since the early thirties, was the result of an insufficient demand for investible funds as well as the "easy money" policy of the Federal Government. Actually, a fundamentally weak situation from the standpoint of the lender was gradually developing throughout the I920's, and this weakness became apparent when the

* This article has been prepared with the aid of Orson H. Hart, Carolyn E. Holt, and Elizabeth Shaul! of the Investment Research Staff of the Life Insurance Association of America.

t B.A. 1936, M.A. 1937, Wesleyan University; Ph.D. 194r, Duke University. Director of Investment Research, Life Insurance Association of America. 
TABLE I

Net Rates of Interest Earned on INVested Funds, I9I5-I950

ALL U. S. LIFE INSURANCE COMPANIES

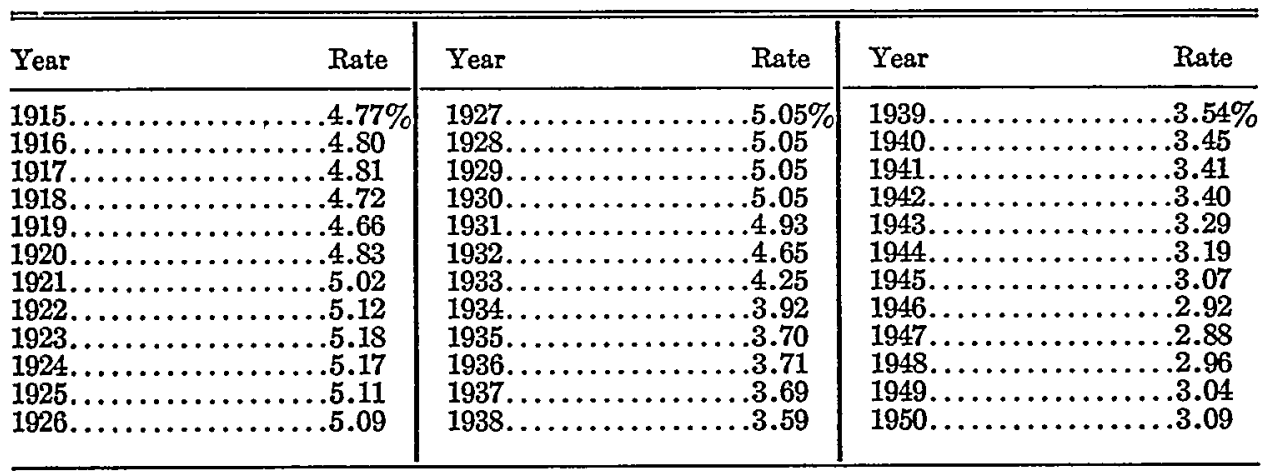

Bource: Institute of Life Insurance: Lifre Irsorasce FACT Boor, 1951, 50

Note: The net interest rate is the ratio of the net investment income for the year to the mean ledger assets decreased by one-haif the net investment income.

easy money policy of the I930's was launched. Demand for capital in the private economy did not respond to the lure of depressed interest rates. Instead, vast waves of refunding engulfed the market for outstanding obligations and the insurance companies found themselves investing, in addition to their newly acquired funds, an increasing inflow of cash arising from the turnover of their existing mortgage and security holdings.

Apart from its direct effect on interest rates, the languishing demand for investment funds in the private economy caused the life insurance companies to invest an increasing proportion of their assets in United States Government bonds, the volume of which was being expanded by deficit financing, thus reducing still more the yield on their funds. The outbreak of war in I94I greatly speeded up this process. As shown in Table 2, 46 per cent of the assets of all United States companies were invested in United States Government bonds by the end of the war. The subsequent decline in this proportion to $2 \mathrm{I}$ per cent in I950, coupled with the enormous demand for capital funds from private sectors of the economy in the postwar period, was largely responsible for the modest improvement in investment yields over the past few years.

No breakdown of investment yields by lines of enterprise is available for the entire life insurance business. However, a study of the bond investments, by lines of enterprise, of the I8 largest United States life companies is available for the years rg29 through 1950. In addition the Investment Research Program of the Life Insurance Association of America has developed some data on mortgage yields.

Table 3 shows yields on bonds, by lines of enterprise, for the 18 largest United States life companies for the years I929-I950. These are gross yields-that is, yields before the deduction of investment expenses-and are based on portfolios valued at actual cost rather than book value. It should be noted that the yield on Govern- 
TABLE 2

Distribution of Assets, I921-T950

ALL U. S. LIFE INSURANCE COMPANIES

(Dollar amounts in billions)

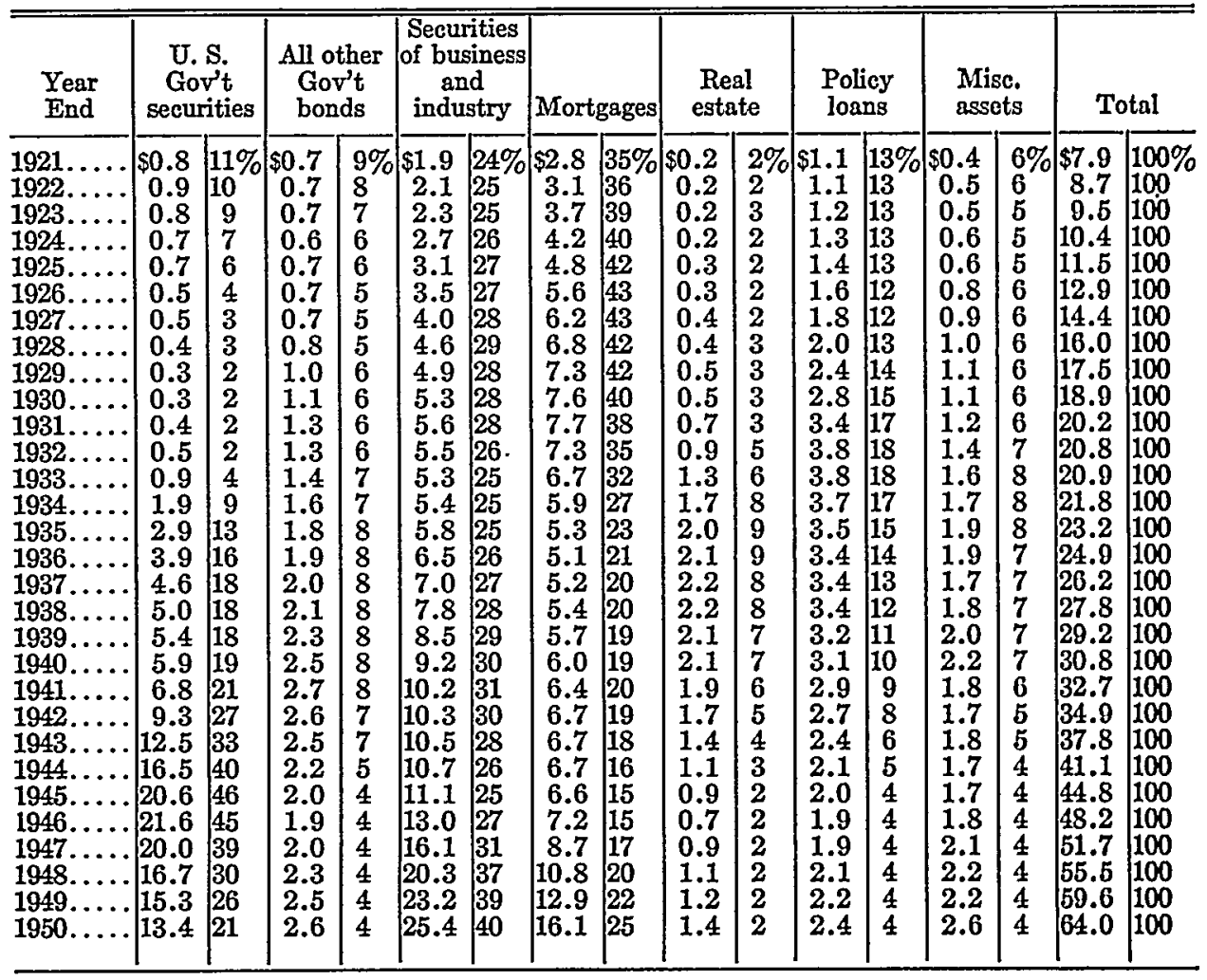

Source: Institute of Life Insurance :Ltre Insomunce Fuct Boor, 1951, 51, 56.

Note: Components may not add to totals due to rounding.

ments is not merely the yield on United States Governments but on foreign governments as well.

The pattern of yields is much the same as that shown for assets of all companies in Table $x$, but the magnitude of the declines varied considerably among the different categories. We should also note two other points. One is that the yield obtained on the securities of private business establishments exceeded the yield obtained on Governments by more in I950 than it did in I929. The difference amounted to at least 50 basis points in I950, a spread of some consequence when the over-all yield structure is in the neighborhood of 3 per cent. The other is that railroad bonds, though causing much anxiety pricewise, have shown a good record from the standpoint of interest earnings.

The I8 company study also provides some interesting data on over-all performance of bond investment-that is, interest yields plus or minus the profit or loss on 
TABLE 3

RATES OF INTEREST RETURN ON BONDS, I929-I950

I8 U. S. LIFE INSURANCE COMPANIES

\begin{tabular}{|c|c|c|c|c|c|c|}
\hline Year & Gov'ts & $\begin{array}{l}\text { States and } \\
\text { mcpls. }\end{array}$ & Rails & Utilities & $\begin{array}{l}\text { Ind'ls and } \\
\text { misc. }\end{array}$ & Total \\
\hline 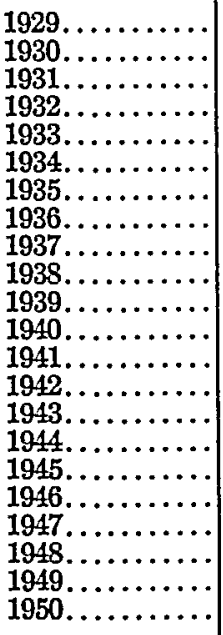 & $\begin{array}{l}4.56 \% \\
4.26 \\
4.24 \\
3.90 \\
3.38 \\
2.92 \\
2.67 \\
2.73 \\
2.79 \\
2.74 \\
2.73 \\
2.72 \\
2.56 \\
2.49 \\
2.47 \\
2.41 \\
2.35 \\
2.45 \\
2.45 \\
2.46 \\
2.46 \\
2.52\end{array}$ & $\begin{array}{l}4.84 \% \\
4.73 \\
4.60 \\
4.52 \\
4.41 \\
4.45 \\
4.31 \\
4.21 \\
4.05 \\
3.95 \\
3.96 \\
3.90 \\
3.77 \\
3.86 \\
3.78 \\
3.86 \\
4.02 \\
3.79 \\
3.85 \\
3.56 \\
3.49 \\
3.48\end{array}$ & $\begin{array}{l}4.62 \% \\
4.61 \\
4.55 \\
4.52 \\
4.20 \\
4.13 \\
3.89 \\
3.88 \\
3.73 \\
3.45 \\
3.51 \\
3.47 \\
3.67 \\
4.19 \\
3.76 \\
4.09 \\
4.48 \\
3.81 \\
3.88 \\
3.83 \\
3.78 \\
3.77\end{array}$ & $\begin{array}{l}4.96 \% \\
5.04 \\
4.95 \\
4.88 \\
4.85 \\
4.84 \\
4.78 \\
4.29 \\
4.08 \\
3.90 \\
3.64 \\
3.59 \\
3.48 \\
3.44 \\
3.40 \\
3.39 \\
3.33 \\
3.12 \\
2.97 \\
2.98 \\
3.06 \\
3.03\end{array}$ & $\begin{array}{l}4.66 \% \\
4.91 \\
4.92 \\
4.46 \\
4.24 \\
4.24 \\
4.03 \\
3.78 \\
3.69 \\
3.42 \\
3.46 \\
3.17 \\
2.80 \\
2.98 \\
3.09 \\
3.17 \\
3.35 \\
2.77 \\
2.81 \\
3.00 \\
3.09 \\
3.06\end{array}$ & $\begin{array}{l}4.72 \% \\
4.72 \\
4.65 \\
4.56 \\
4.30 \\
4.12 \\
3.82 \\
3.63 \\
3.51 \\
3.35 \\
3.32 \\
3.26 \\
3.16 \\
3.18 \\
3.00 \\
2.93 \\
2.86 \\
2.74 \\
2.74 \\
2.81 \\
2.88 \\
2.92\end{array}$ \\
\hline Av. $1929-50 \ldots$ & 2.52 & 4.02 & 3.98 & 3.53 & 3.13 & 3.16 \\
\hline
\end{tabular}

Source: Life Insurance Association of America: Investwems Butr. No. 78, App. B, Table 7. Data for 1950 and 1929-1950 averages rre taken from the files of the Investment Resesrch Department, LIAA. Rates for the years 1929 through 1944 were based on data

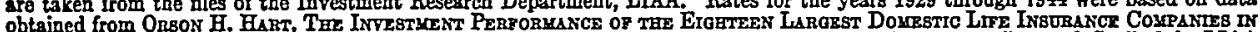

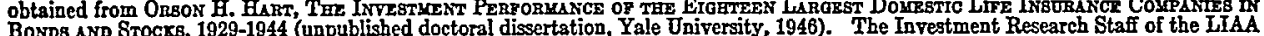
BoNDS AND STOCKB, 1929-1944 (unpublished doctoral dissertstion, Yale University

has extended the series developed by Dr. Hart for the years 1945 through 1950 .
Note: Data show the ratio of interest earnings to the average cost of portfolio as of the beginning and end of the year. Accrued interest is included in portfolio.

disposal of bonds. As in the previous table, the basis of computations is cost, not book value. Profits and losses are assumed to materialize in the year in which the bonds are moved out of the portfolios. These data, shown in Table 4, illustrate the remarkable ability of the life insurance companies to withstand the stresses that sometimes arise in the capital markets. The total return on rail bonds was maintained very well during the r930's when increasingly large segments of the railroad industry were entering bankruptcy. All but terminating the net acquisition of railroad bonds, the life insurance companies let the growth of assets reduce the proportion in rails, watched developments in the industry, and in due time sold or wrote off the most troublesome situations. Taking the average over the entire period r 929 through I950, the total rate obtained by the companies on rail bonds hardly differed from that obtained on utilities.

Dr. Raymond J. Saulnier of the staff of the National Bureau of Economic Research, with the aid of a grant from the Life Insurance Association of America, has produced some interesting data on mortgage loans of life insurance companies. Saulnier used a representative sample of straight urban mortgage loans made by 24 


\section{TABLE 4}

Total Rates of Return on Funds Invested in Bonds, 1929-1950

I8 U. $S$. IIFE INSURANCE COMPANIES

\begin{tabular}{|c|c|c|c|c|c|c|}
\hline Year & Gov'ts & $\begin{array}{l}\text { States and } \\
\text { mcpls. }\end{array}$ & Rails & Utilities & $\begin{array}{l}\text { Ind'ls and } \\
\text { misc. }\end{array}$ & Total \\
\hline 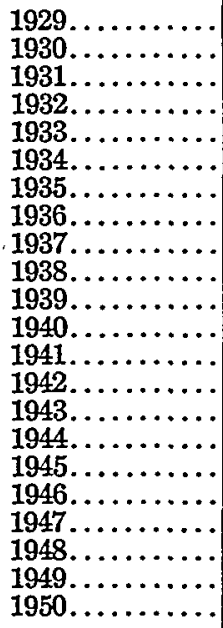 & $\begin{array}{l}4.56 \% \\
4.86 \\
3.42 \\
3.60 \\
3.03 \\
3.24 \\
2.79 \\
2.83 \\
2.72 \\
2.91 \\
2.80 \\
2.97 \\
2.60 \\
2.69 \\
3.16 \\
2.61 \\
2.77 \\
2.72 \\
2.60 \\
2.53 \\
2.58 \\
2.73\end{array}$ & $\begin{array}{l}4.83 \% \\
4.75 \\
4.61 \\
4.49 \\
4.44 \\
4.45 \\
4.30 \\
4.23 \\
3.81 \\
4.01 \\
4.00 \\
4.05 \\
3.86 \\
4.94 \\
4.95 \\
6.63 \\
7.77 \\
5.33 \\
4.40 \\
3.73 \\
3.49 \\
3.60\end{array}$ & $\begin{array}{l}4.66 \% \\
4.60 \\
4.52 \\
4.49 \\
4.17 \\
3.84 \\
3.92 \\
4.09 \\
3.73 \\
3.42 \\
3.46 \\
3.21 \\
2.54 \\
1.44 \\
2.70 \\
3.22 \\
6.41 \\
4.50 \\
2.77 \\
3.67 \\
3.81 \\
4.02\end{array}$ & $\begin{array}{l}\mathbf{5 . 0 0 \%} \\
5.01 \\
\mathbf{5 . 3 9} \\
4.91 \\
4.83 \\
4.88 \\
5.47 \\
\mathbf{5 . 2 9} \\
4.56 \\
4.36 \\
4.12 \\
3.69 \\
3.75 \\
3.52 \\
3.57 \\
3.81 \\
4.07 \\
3.38 \\
3.09 \\
2.99 \\
3.10 \\
3.15\end{array}$ & $\begin{array}{l}5.01 \% \\
4.95 \\
4.98 \\
4.25 \\
4.30 \\
4.39 \\
4.43 \\
4.46 \\
3.61 \\
3.66 \\
3.93 \\
3.84 \\
3.03 \\
3.06 \\
3.11 \\
3.69 \\
4.69 \\
3.22 \\
2.91 \\
3.03 \\
3.16 \\
3.14\end{array}$ & $\begin{array}{l}4.77 \% \\
4.76 \\
4.70 \\
4.51 \\
4.25 \\
4.08 \\
4.02 \\
3.97 \\
3.55 \\
3.53 \\
3.49 \\
3.40 \\
3.05 \\
2.92 \\
3.31 \\
3.21 \\
3.67 \\
3.09 \\
2.78 \\
2.84 \\
2.96 \\
3.07\end{array}$ \\
\hline Av. $1929-50 . .$. & 2.73 & 4.51 & 3.75 & 3.77 & 3.34 & 3.32 \\
\hline
\end{tabular}

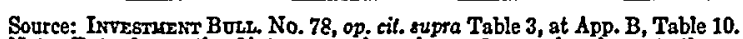

Note: Data show ratio of interest earnings plus profits or minus losses to tho average cost of portfolio as of tho beginning and cndlof the year. Accrued interest is included in portfolio.

companies to produce a series on contractual rates for the years rg20 through r947. These data are shown in Table 5.

The high point in the series, both for I-4 family dwellings and for all other property, was I921, after which no appreciable trend developed until the r930's. Then, as might be expected, the contractual rate for both kinds of property began a substantial decline. In the case of loans on I-4 family dwellings, the decline was from 6 per cent in I930 to 4 per cent in 1947; for loans on all other property the decline was from 5.9 per cent to 4 per cent.

Saulnier has also produced data on gross and net rates of mortgage income of life insurance companies based on reports from a varying number of companies for the years I945 through 1947. These data have been computed since r947 by the Investment Research Staff of the Life Insurance Association of America. Hence, a five-year record is now available-not enough to establish trends but enough to provide considerable understanding of investment costs and the general level of yields in recent years. The high cost of acquiring and servicing mortgage loans, particularly farm loans, absorbs a goodly proportion of the gross yields. 
TABLE 5

Contract Interest Rates on a Sample of Straight Urban Mortgage Loans

Classified by Type of Property, I920-1947

24 LIFE INSURANCE COMPANIES

\begin{tabular}{|c|c|c|c|c|}
\hline \multirow{2}{*}{ Year made } & \multicolumn{2}{|c|}{ 14 FAMILT DWELINGS } & \multicolumn{2}{|c|}{ All Other Propertx } \\
\hline & $\begin{array}{l}\text { Number of } \\
\text { loans made }\end{array}$ & $\begin{array}{l}\text { Average contract } \\
\text { interest rates }\end{array}$ & $\begin{array}{l}\text { Number of } \\
\text { Ioans made }\end{array}$ & $\begin{array}{l}\text { Average contract } \\
\text { interest rates }\end{array}$ \\
\hline 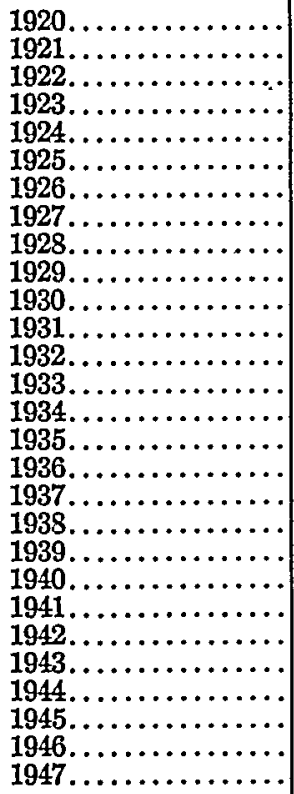 & $\begin{array}{r}73 \\
119 \\
170 \\
209 \\
279 \\
358 \\
478 \\
414 \\
411 \\
396 \\
347 \\
299 \\
98 \\
15 \\
26 \\
64 \\
163 \\
192 \\
255 \\
285 \\
404 \\
584 \\
613 \\
459 \\
286 \\
235 \\
311 \\
72\end{array}$ & $\begin{array}{l}6.1 \% \\
6.2 \\
6.1 \\
5.9 \\
5.9 \\
5.9 \\
5.8 \\
5.9 \\
5.9 \\
6.0 \\
6.0 \\
6.0 \\
6.0 \\
5.9 \\
5.8 \\
5.5 \\
5.2 \\
5.1 \\
5.1 \\
4.9 \\
4.6 \\
4.6 \\
4.5 \\
4.5 \\
4.5 \\
4.4 \\
4.2 \\
4.0\end{array}$ & $\begin{array}{r}13 \\
16 \\
22 \\
29 \\
38 \\
42 \\
49 \\
44 \\
47 \\
56 \\
27 \\
16 \\
7 \\
33 \\
14 \\
21 \\
22 \\
26 \\
33 \\
26 \\
38 \\
22 \\
14 \\
14 \\
18 \\
22 \\
1\end{array}$ & $\begin{array}{l}5.8 \% \\
6.5 \\
5.9 \\
5.7 \\
5.8 \\
5.4 \\
5.6 \\
5.5 \\
5.3 \\
5.7 \\
5.9 \\
5.4 \\
5.3 \\
\ddot{4.5} \\
5.3 \\
4.6 \\
5.1 \\
4.7 \\
4.6 \\
4.4 \\
4.3 \\
4.5 \\
4.2 \\
3.9 \\
4.2 \\
4.2 \\
4.0\end{array}$ \\
\hline
\end{tabular}
1950).

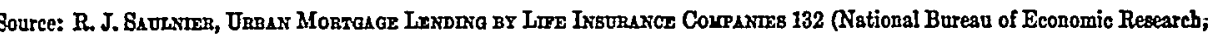

\section{Commercial Banks}

There are series on investment yields covering all insured commercial banks as well as all member banks of the Federal Reserve System. Although the series for all member banks is less inclusive, the data it provides for the pre-depression years render it more useful for a study of trends. The all-insured-commercial-bank series goes back only to I934.

The trend in yields for all member banks, shown in Table 7, reveals the now familiar pattern-a substantial decline throughout the 1930's and the war years followed by an upturn after the war. The upturn since 1945 reflects the increasing proportion of loans in the porffolios and the highly favorable trend of loan yields.

The pattern is familiar in another respect too-like the life insurance companies the member banks invested an increasing proportion of their funds in United States 
Government obligations during the r930's and the war years, while during the postwar period their holdings of United States Governments declined both absolutely and as a proportion of total assets. The peak of Government securities holdings was reached in 1945, amounting to 78 billion dollars. Holdings at the end of 1950 amounted to 52 billion dollars. The difficulty of finding suitable investments in the face of the easy money programs caused cash and reserves to outdistance loans during the middle of the 1930's, and by the end of the war United States Government issues, generally of shorter term than those held by the life companies, accounted for over half of the banks' total assets. These changes in the composition of assets, shown in Table 8, thus brought into the banks' portfolios an increasing proportion of low-yielding investments, and accentuated the trend brought about by the decline in interest rates. United States Government obligations still accounted for $3^{6}$ per cent of the member banks' assets at the end of 1950 .

\section{III}

\section{Mutuar Savings Banks}

Data on the investment earnings of mutual savings banks have been compiled by the Federal Deposit Insurance Corporation for insured institutions only. These appear to be the best publicly available data on investment yields of mutual savings banks, though they are not without shortcomings. Assets of insured mutual savings banks were only about to per cent of the assets of all mutual savings banks in 1934,

\section{TABLE 6}

Average Gross and Net Rates of Income from Mortgage Loans and

Real Estate Sales Contracts, 1945-T950 SELECTED UNITED STATES LIFE INSURANCE COMPANIES

\begin{tabular}{|c|c|c|c|c|}
\hline Year & Gross income & Net income & $\begin{array}{l}\text { Number of } \\
\text { companies covered }\end{array}$ & $\begin{array}{c}\text { Approximato } \\
\text { coverage of loans } \\
\text { of life companies }\end{array}$ \\
\hline \multicolumn{5}{|c|}{ Urban Loans } \\
\hline $\begin{array}{l}1945 \ldots \ldots \ldots \ldots \\
1946 \ldots \ldots \ldots \ldots \\
1947 \ldots \ldots \ldots \ldots \ldots \\
1948 \ldots \ldots \ldots \ldots \\
1949 \ldots \ldots \ldots \ldots \\
1950 \ldots \ldots \ldots \ldots \ldots\end{array}$ & $\begin{array}{l}4.38 \% \\
4.18 \\
4.07 \\
4.06 \\
4.11 \\
4.04\end{array}$ & $\begin{array}{l}3.77 \% \\
3.40 \\
3.19 \\
3.19 \\
3.30 \\
3.28\end{array}$ & $\begin{array}{l}52 \\
52 \\
43 \\
74 \\
75 \\
80\end{array}$ & $\begin{array}{l}40 \% \\
40 \\
50 \\
60 \\
75 \\
80\end{array}$ \\
\hline \multicolumn{5}{|c|}{ Farm Loans } \\
\hline $\begin{array}{l}1945 \ldots \ldots \ldots \ldots \ldots \\
1946 \ldots \ldots \ldots \ldots \ldots \\
1947 \ldots \ldots \ldots \ldots \ldots \\
1948 \ldots \ldots \ldots \ldots \\
1949 \ldots \ldots \ldots \ldots \ldots \\
1950 \ldots \ldots \ldots \ldots\end{array}$ & $\begin{array}{l}4.63 \% \\
4.47 \\
4.24 \\
4.10 \\
3.98 \\
4.01\end{array}$ & $\begin{array}{l}3.74 \% \\
3.34 \\
2.82 \\
2.72 \\
2.67 \\
2.85\end{array}$ & $\begin{array}{l}29 \\
31 \\
21 \\
36 \\
33 \\
38\end{array}$ & $\begin{array}{l}65 \% \\
65 \\
55 \\
75 \\
80 \\
85\end{array}$ \\
\hline
\end{tabular}

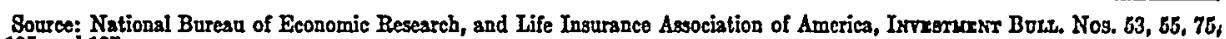
76, $125 ;$ and 127 .

Note: Gross income dats and total costs used in arriving at net income were reported on a cash, not an accrual, basis. In periods of expandiog mortgage lending activity, income on a cash basis tends to be lower and costs tend to be higher than thoso on an accrual bauf. 
TABLE 7

Gross Rates of Income on LoAns and Securittes, I927-I950

ALL MEMBER BANKS

\begin{tabular}{|c|c|c|c|c|}
\hline Year & Loans & Securities & $\begin{array}{l}\text { Loans and securities } \\
\text { combined }\end{array}$ & 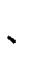 \\
\hline 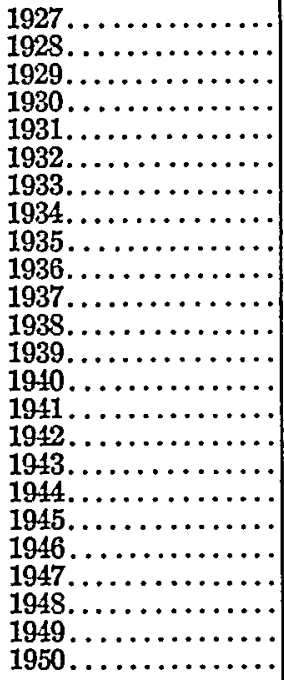 & $\begin{array}{l}5.5 \% \\
5.7 \\
6.1 \\
5.4 \\
5.0 \\
5.1 \\
4.7 \\
4.3 \\
4.2 \\
4.1 \\
4.0 \\
4.1 \\
4.2 \\
4.2 \\
4.0 \\
3.8 \\
3.5 \\
3.2 \\
3.0 \\
3.2 \\
3.55 \\
3.82 \\
4.04 \\
4.17\end{array}$ & $\begin{array}{l}4.7 \% \\
4.7 \\
4.7 \\
4.6 \\
4.1 \\
3.9 \\
3.5 \\
3.3 \\
2.8 \\
2.6 \\
2.6 \\
2.5 \\
2.3 \\
2.1 \\
1.9 \\
1.7 \\
1.4 \\
1.5 \\
1.5 \\
1.5 \\
1.59 \\
1.63 \\
1.66 \\
1.64\end{array}$ & $\begin{array}{l}5.2 \% \\
5.4 \\
5.7 \\
5.1 \\
4.6 \\
4.6 \\
4.1 \\
3.8 \\
3.3 \\
3.2 \\
3.2 \\
3.1 \\
3.1 \\
2.9 \\
2.7 \\
2.5 \\
1.9 \\
1.8 \\
1.8 \\
1.9 \\
2.2 \\
2.4 \\
2.5 \\
2.6\end{array}$ & \\
\hline
\end{tabular}

Sources: Burgme pro Moprest STAтstics (Board of Governors of the Federal Reserve System, Washington. D. C., 1943); Froxar Rrstrye Botritrs, Jure 1946, May 1947, May 1951. Rates for loans and securities combined were computed by the Invest-

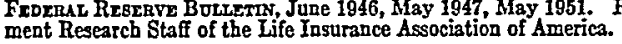

when this series began. Even by 1942 they accounted for only about I9 per cent of the total. The increase in the number of insured banks in I943-from $5^{6}$ to $184-$ brought their assets to 64 per cent of the total, and there has been a modest increase since then to around $7 \mathrm{I}$ per cent in 1950 . Thus, although yield data appear in , Table 9 for the years 1934 through 1950, those for the years prior to I943 probably. are not representative of the experience of mutual savings banks as a group.

The limited period for which comparable figures are available together with the small proportion of savings bank assets included for the years prior to r943 makes it difficult to draw firm conclusions regarding the trend of yields. In fact, the rates for the earlier period, when the total number of insured mutual banks was small, seem to reflect fluctuations in the number of banks included more than changes in rates of income. We are probably safe in assuming, however, that the trend during the I930's was downward. Certainly the recovery after 1947 in the combined rate for loans and securities has been moderate.

The rates on securities shown in Table 9 are, of course, heavily weighted by the rate earned on United States Governments. During the I930's and the war period, holdings of United States Governments assumed even greater importance among the assets of mutual savings banks than was true of the other financial institutions 
TABLE 8

Distrubution of Assets, 1927-1950

ALI MEMBER BANKS

(Dollar amounts in billions)

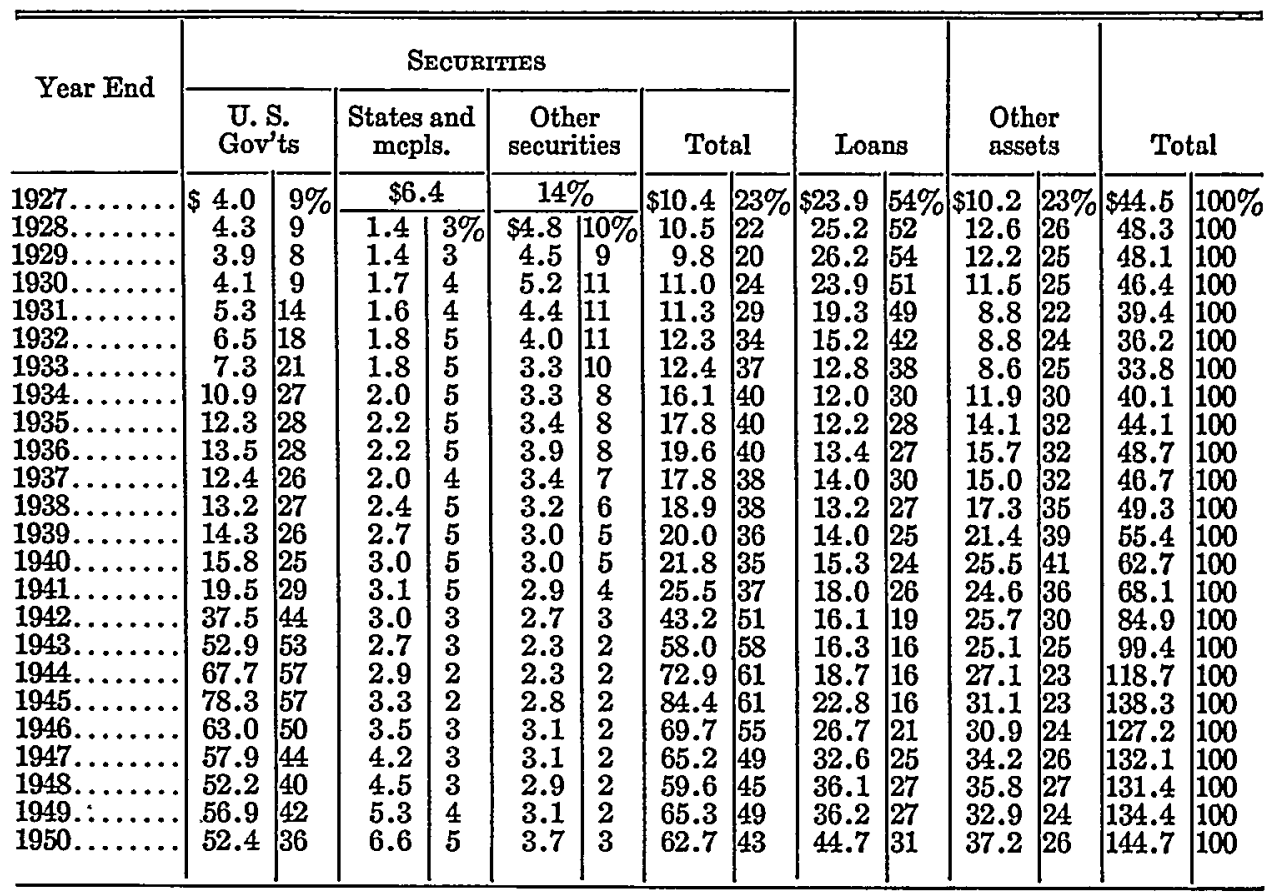

Sources: Bankino and Monerarr Sramestca (Board of Governors of the Federal Reserve System, Waghington, D. C., 1943); Frozal Reserve BuLnerns. Total assgts for 1942 through 1950 were furnished by tho Federal Reservo Bank of Nor York. Note: Components may not add to totals due to rounding.

covered in this paper. The slight upturn after 1947 in the rate on securities was due primarily to a somewhat increased investment in other securities, largely corporate obligations. The rates received on loans-almost exclusively mortgage loans in the case of mutual savings banks-have been relatively favorable but it should be noted that these rates have declined in each of the postwar years. These declines accompanied an expansion in mortgage investment after the war and were due in large part to an increased proportion of mortgage loans partially or fully guaranteed by the Federal Government.

Changes in the investments of all mutual savings banks can be seen from Table 10: Although the Comptroller of the Currency and the National Association of Mutual Savings Banks provide asset data for these banks for earlier years, it seemed preferable to use the series covering all mutual savings banks compiled by the Federal Deposit Insurance Corporation, the source of earnings data for insured institutions. 
TABLE 9

Gross Rates of Income on Loans and Securities, I934-I950 INSURED MUTUAL SAVINGS BANKS

\begin{tabular}{|c|c|c|c|}
\hline Year & Loans & Securities & $\begin{array}{l}\text { Loans and securities } \\
\text { combined }\end{array}$ \\
\hline 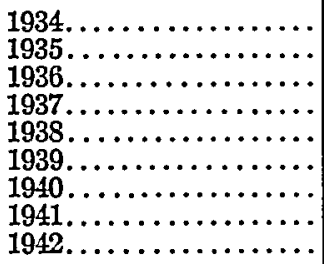 & $\begin{array}{l}4.43 \% \\
3.94 \\
3.95 \\
3.99 \\
4.36 \\
4.58 \\
4.55 \\
4.34 \\
4.67\end{array}$ & $\begin{array}{l}4.09 \% \\
3.59 \\
3.44 \\
3.14 \\
3.13 \\
3.63 \\
3.93 \\
3.02 \\
2.98\end{array}$ & $\begin{array}{l}4.28 \% \\
3.77 \\
3.70 \\
3.55 \\
3.73 \\
4.08 \\
4.19 \\
3.52 \\
3.62\end{array}$ \\
\hline $\begin{array}{l}1943 \ldots \ldots \ldots \ldots \ldots \ldots \\
1944 \ldots \ldots \ldots \ldots \ldots \\
1915 \ldots \ldots \ldots \ldots \ldots \\
1946 \ldots \ldots \ldots \ldots \ldots \\
1947 \ldots \ldots \ldots \ldots \ldots \ldots \\
1948 \ldots \ldots \ldots \ldots \ldots \ldots \\
1919 \ldots \ldots \ldots \ldots \ldots \ldots \\
1950 \ldots \ldots \ldots \ldots \ldots\end{array}$ & $\begin{array}{l}4.44 \\
4.53 \\
4.61 \\
4.58 \\
4.51 \\
4.43 \\
4.37 \\
4.35\end{array}$ & $\begin{array}{l}2.54 \\
2.38 \\
2.31 \\
2.35 \\
2.34 \\
2.38 \\
2.44 \\
2.45\end{array}$ & $\begin{array}{l}3.38 \\
3.17 \\
3.02 \\
2.97 \\
\mathbf{2 . 9 4} \\
\mathbf{2 . 9 8} \\
\mathbf{3 . 0 6} \\
\mathbf{3 . 1 5}\end{array}$ \\
\hline
\end{tabular}

Source: Anwuar Rrports of tar Prograt Depostr Insurance Conporation. For some gears rates on loans and on securities, and forallyears rates on loans and zecurities combined, were computed by the Investment Research Stafi of the Life Insurance Association of America

TABLE Io

Distribution of Assets, I935-I950

AIL MUTUAL SAVINGS BANKS

(Dollar amounts in billions)

\begin{tabular}{|c|c|c|c|c|c|c|c|c|c|c|c|c|}
\hline \multirow{3}{*}{$\begin{array}{c}\text { Year End } \\
1935 \ldots \ldots \ldots\end{array}$} & \multicolumn{6}{|c|}{ Securtties } & & & & & & \\
\hline & \multicolumn{2}{|c|}{$\begin{array}{l}\text { U. S. } \\
\text { Gov'ts }\end{array}$} & \multicolumn{2}{|c|}{ Other } & \multicolumn{2}{|c|}{ Tatal } & \multicolumn{2}{|c|}{$\begin{array}{l}\text { Loans and } \\
\text { discounts }\end{array}$} & \multicolumn{2}{|c|}{$\begin{array}{l}\text { Other } \\
\text { assets }\end{array}$} & \multicolumn{2}{|c|}{ Total } \\
\hline & $\$ 1.7$ & $15 \%$ & $\$ 2.9$ & $26 \%$ & $\$ 4.6$ & $41 \%$ & $\$ 5.1$ & $46 \%$ & $\$ 1.4$ & $13 \%$ & $\$ 11.2$ & $100 \%$ \\
\hline $1936 \ldots \ldots$ & 2.2 & $19^{70}$ & 2.7 & 24 & 4.9 & 43 & 5.0 & $44^{\prime \prime}$ & 1.5 & $13^{10}$ & 11.4 & $100^{10}$ \\
\hline $1937 \ldots \ldots \ldots$ & 2.5 & 21 & 2.7 & 23 & 5.1 & 45 & 4.9 & 43 & 1.5 & 13 & 11.5 & 100 \\
\hline $1938 \ldots \ldots \ldots$ & 2.9 & 25 & 2.4 & 20 & 5.3 & 45 & 4.9 & 42 & 1.5 & 13 & 11.6 & 100 \\
\hline $1939 \ldots \ldots$ & 3.1 & 26 & 2.2 & 18 & 5.3 & 45 & 4.9 & 41 & 1.7 & 14 & 11.8 & 100 \\
\hline $1940 \ldots \ldots$ & 3.2 & 27 & 2.1 & 17 & 5.3 & 44 & 4.9 & 41 & 1.7 & 15 & 11.9 & 100 \\
\hline $1941 \ldots$ & 3.7 & 31 & 1.8 & 15 & 5.5 & 46 & 4.9 & 41 & 1.4 & 12 & 11.8 & 100 \\
\hline $1942 \ldots$ & 4.6 & 38 & 1.5 & 12 & 6.0 & 50 & 4.7 & 39 & 1.2 & 10 & 11.9 & 100 \\
\hline $1943 .$. & 6.1 & 47 & 1.3 & .10 & 7.4 & 57 & 4.5 & 34 & 1.2 & 9 & 13.1 & 100 \\
\hline $1914 \ldots$ & 8.3 & 56 & 1.2 & 8 & 9.6 & 65 & 4.4 & 30 & 0.9 & 6 & 14.8 & 100 \\
\hline $1945 \ldots$ & 10.7 & 63 & $\overline{1} . \overline{3}$ & 7 & 11.9 & 70 & 4.3 & 25 & 0.8 & 5 & 17.0 & 100 \\
\hline $1946 \ldots$ & 11.8 & 63 & 1.4 & 7 & 13.2 & 70 & 4.5 & 24 & 1.0 & 5 & 18.7 & 100 \\
\hline $1947 \ldots$ & 12.0 & 61 & 1.7 & 9 & 13.7 & 69 & 4.9 & 25 & 1.1 & 5 & 19.7 & 100 \\
\hline $1948 \ldots$ & 11.5 & 56 & 2.2 & 11 & 13.7 & 67 & 5.7 & 28 & 1.1 & 5 & 20.5 & 100 \\
\hline $1949 \ldots$ & 11.4 & 53 & 2.4 & 11 & 13.8 & 64 & 6.6 & 31 & 1.1 & 5 & 21.5 & 100 \\
\hline $1950 \ldots$ & 10.9 & 49 & 2.3 & 10 & 13. & 59 & 8.1 & 36 & 1.0 & 5 & 22.4 & 100 \\
\hline
\end{tabular}

Source: ANndal Reports of the Federat Deposit Insorance Corporation.

Note: Components may not add to totals due to rounding. 


\section{IV}

\section{Savings and Loan Associations}

There is little published data on the yields of savings and loan associations. However, through the courtesy of the United States Savings and Loan League, yields on mortgage loans of associations that are members of the Federal Home Loan Bank System have been furnished for the years 1938 through I950. The fragmentary nature of the figures, together with changes in the number of reporting member associations, makes data prior to 1938 unsatisfactory. It appears that there may have been incomparability of reporting as late as r94I-r942. The League also has computed yields on United States Governments beginning with 194I-these obligations did not assume any importance in the portfolios of savings and loan associations until I94I and after. From the yields supplied by the United States Savings and Loan League the Investment Research Staff of the Life Insurance Association has estimated approximate over-all yields for both mortgages and United States Governments. These are shown in Table rr.

\section{TABLE II}

Gross Rates of Income on Mortgage Loans and U. S. GovernmentsSavings and Loan Associations-Members of the Federal Home Loan Bank System

\begin{tabular}{|c|c|c|c|}
\hline Year & Mortgage loans & U. S. Gov'ts & $\begin{array}{l}\text { Mortgage loans and } \\
\text { U. S. Gov'ts combined }\end{array}$ \\
\hline 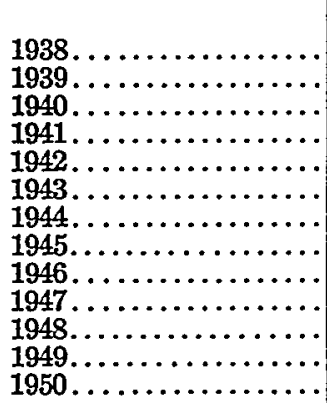 & $\begin{array}{l}4.85 \% \\
4.98 \\
5.44 \\
5.58 \\
5.76 \\
5.51 \\
5.43 \\
5.24 \\
5.00 \\
4.79 \\
4.79 \\
4.80 \\
4.82\end{array}$ & $\begin{array}{l}\text { n. a. } \\
\text { n. a. } \\
\text { n. a. } \\
2.87 \% \\
1.56 \\
1.62 \\
1.75 \\
1.86 \\
2.24 \\
2.30 \\
2.34 \\
2.37 \\
2.35\end{array}$ & $\begin{array}{l}\text { (Estimated) } \\
\text { n. a. } \\
\text { n. a. } \\
\text { n. a. } \\
5.54 \% \\
5.59 \\
5.08 \\
4.65 \\
4.27 \\
4.28 \\
4.33 \\
4.45 \\
4.52 \\
4.57\end{array}$ \\
\hline
\end{tabular}

n. a.-not available.

Bource: Rates on mortgage loans and on United States Governments were obtained from the United States Savings and Ioan Ireaguo

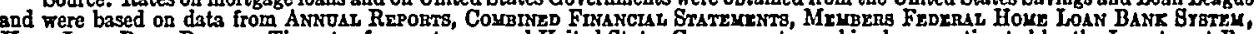
Houg LoAs BAxx BoARD. The rates for mortgages and United States Gorernments combined wero estimated by tho Investment Ro. search Staff of the Life Insurance Association of America.

Like other financial institutions, the savings and loan associations increased their investments in United States Governments during the war. But the proportion of their assets thus invested never reached the levels attained by life insurance companies, commercial banks, or mutual savings banks. The peak for all savings and loan associations was about $3^{\circ}$ per cent in 1945, and most of the remaining assets consisted of residential mortgages. The comparatively low rates obtained on United States Governments, particularly during the war, therefore did not unduly burden 
TABLE I2

Distrubutron of Assets

ALL SAVINGS AND IOAN ASSOCIATIONS, I929-I950

(Dollar amounts in billions)

\begin{tabular}{|c|c|c|c|c|c|c|c|c|c|c|c|c|}
\hline \multirow{2}{*}{$\frac{\text { Year end }}{1929 \ldots \ldots \ldots}$} & \multicolumn{2}{|c|}{$\begin{array}{l}\text { Mortgage } \\
\text { loans }\end{array}$} & \multicolumn{2}{|c|}{$\begin{array}{c}\text { Real } \\
\text { estate }\end{array}$} & \multicolumn{2}{|c|}{$\begin{array}{l}\text { Government } \\
\text { bonds }\end{array}$} & \multicolumn{2}{|c|}{ Cash } & \multicolumn{2}{|c|}{$\begin{array}{l}\text { Other } \\
\text { assets }\end{array}$} & \multicolumn{2}{|c|}{ Total } \\
\hline & $\$ 7.8$ & $90 \%$ & $\$ 0.2$ & $3 \%$ & \$n. a. & n. a.\% & $\$ 0.4$ & $5 \%$ & $\$ 0.2$ & $3 \%$ & $\$ 8.7$ & $100 \%$ \\
\hline $1930 . . . \ldots \ldots$ & 7.8 & 88 & 0.3 & 3 & n. a. & a. a. & 0.5 & 6 & 0.3 & 3 & 8.8 & 100 \\
\hline 1931 . & 7.2 & 86 & 0.4 & 5 & n. a. & n. a. & 0.4 & 5 & 0.4 & 5 & 8.4 & 100 \\
\hline 1932. & 6.4 & 83 & 0.7 & 8 & n. a. & n. a. & 0.3 & 4 & 0.4 & 5 & 7.8 & 100 \\
\hline 1933 & 5.4 & 78 & 0.8 & 12 & n. a. & $\begin{array}{l}\text { n. a. } \\
\text { n. a. }\end{array}$ & 0.3 & 5 & 0.4 & $\begin{array}{l}0 \\
6\end{array}$ & 7.0 & 100 \\
\hline 1934. & 4.5 & 70 & 1.0 & 16 & n. a. & n. a. & 0.3 & 4 & 0.7 & 10 & 6.4 & 100 \\
\hline 1935. & 3.9 & 66 & 1.1 & 19 & & ** & 0.2 & 4 & 0.6 & 11 & 5.9 & 100 \\
\hline 36 & 3.7 & 65 & 1.1 & 20 & * & ** & 0.2 & 4 & 0.6 & i1 & 5.7 & 100 \\
\hline & $\begin{array}{l}3.0 \\
3.8\end{array}$ & 67 & 1.0 & 18 & * & ** & 0.2 & 4 & 0 . & 10 & & 100 \\
\hline 38. & 3.9 & 70 & 0.9 & 17 & * & 1 & 0.2 & 4 & 0.5 & 9 & 5.6 & 100 \\
\hline 39 & 4.1 & 72 & 0.7 & 13 & $*$ & 1 & 0.3 & 5 & 0.5 & 9 & 5.7 & 100 \\
\hline & 4.4 & 76 & 0.5 & 9 & 0.1 & $\overline{1}$ & 0.3 & 5 & & 8 & 5 & 100 \\
\hline & 4.8 & 79 & 0.3 & 6 & 0.1 & 2 & 0. & 6 & & 8 & & $100^{\circ}$ \\
\hline & 4.8 & 78 & 0.2 & 3 & 0.3 & 5 & 0.4 & 7 & 0. & 7 & 6.1 & 100 \\
\hline $1943 .$. & 4.9 & 74 & 0.1 & 2 & 0.9 & 14 & 0.5 & 7 & 0.2 & 3 & 6.6 & 100 \\
\hline & 5.0 & 67 & 0.1 & 1 & 1.8 & 24 & 0.4 & 6 & 0 . & 3 & 7 & 100 \\
\hline & 5.5 & 63 & 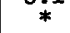 & $* *$ & 2.6 & 30 & 0.4 & 5 & 0. & 2 & 8 & 100 \\
\hline & 7.2 & 71 & * & ** & 2.0 & 20 & 0.5 & 5 & 0. & 4 & 10. & 100 \\
\hline 1947 & 9.0 & 77 & * & ** & 1.8 & 15 & 0.6 & 5 & 0. & 3 & 11 . & 100 \\
\hline & 10.5 & 80 & * & $* *$ & 1.5 & 11 & 0 . & 5 & 0 . & 3 & 13. & 100 \\
\hline & 11. & 80 & * & ** & 1.5 & 10 & 0.8 & 6 & 0 . & 3 & 14 & 100 \\
\hline 1950. & 13.8 & 82 & * & ** & 1.5 & 9 & 0.9 & 6 & 0.6 & 4 & 16.9 & 100 \\
\hline
\end{tabular}

n. a.-not available.

- $\$ 50$ million or less.

*.5 per cent or less.

Source: United States Savings and Ioan Ieague.

Note: Components may not add to totals due to rounding.

the over-all rate of return. The net decline since $194 \mathrm{I}$ in the combined rate reflects predominantly the course of rates on mortgages, the principal investment outlet of the associations. Table $\mathrm{I} 2$ indicates the importance of mortgage loans among the assets of all savings and loan associations.

\section{V}

\section{IMPLICATIONS}

In the preceding sections considerable statistical detail regarding the trend of investment yields of major financial institutions over the last 2 to $2-1 / 2$ decades has been reviewed. The statistics indicated declining trends beginning in some instances as far back as the early I920's, followed by modest improvement in recent years. The downward trend was exaggerated during the I930's and the war period by the increasing proportion of United States Governments in the portfolio compositions, while the improvement over the last few years is traceable in substantial measure to the reduction in the proportion of United States Governments characteristic of most institutional portfolios. This reduction has been 
accompanied, of course, by heavy acquisition of higher-yielding corporate bonds, mortgages, and other loans.

The implications of these trends for financial institutions can be considered under two broad headings: (I) their effects upon investment policy and (2) their effects upon general operating policy.

\section{A. Investment Policy}

The financial institutions responded, each in its own way, to the decline in the trend of investment yields. The savings institutions all felt the decline during the r920's but the reduction was gradual, did not reach very large proportions, and did not affect all markets for loanable funds. Attention was focused on the various limitations which encumbered the investment of life company and savings bank assets. This developed naturally for a combination of reasons. Although the volume of outstanding corporate indebtedness was increasing during the I920's, the increase was at a diminishing rate and the growth of mortgage indebtedness was not enough to take up all of the slack. The United States Government was retiring its indebtedness during this period. Finally, the cheapness of common stock money to users of capital, particularly in the latter part of the decade, induced a considerable volume of bond refunding with stock by prominent American corporations, many of which always had harbored strong aversions to long-term debt in their capital structures.

Accordingly, a liberalization of the New York Insurance Law was proposed, and in 1928 was enacted into law. This amendment was the first substantial relaxation of the limitations which had been inserted into the statutes in 1906 following the Armstrong Report. The amendment permitted life insurance companies domiciled in New York State to invest up to 2 per cent of their assets in the preferred stock of any solvent American corporation meeting certain historical standards respecting earnings and dividends. It further limited investment in such stock to ro per cent of the total outstanding preferred stock of any one issuing institution. Beyond this, it permitted investment in certain unsecured obligations of American corporations.1 The New York Insurance Department observed that, "There is, of course, a limit to the amount of government bonds that are available for investments," and went on to explain the need for the amendment as follows:

... There is a tendency on the part of private corporations to restrict the issuance of mortgage bonds and collateral bonds and to issue in an increasing measure preferred or guaranteed stocks. It seems to be generally recognized that many of the debentures, notes and preferred or guaranteed stocks of private corporations have as great intrinsic value as many of the bonds secured by mortgage or collateral which are now legal investments for life insurance companies. The relative scarcity of securities which are legal investments for life insurance companies has been a factor in reducing the interest yield on such

${ }^{2}$ N. Y. Laws I928, c. 539. 
securities. The policyholders of life insurance companies are entitled to the highest yield on the investments of their companies that is consistent with safety. ${ }^{2}$

The savings banks, investing in much the same outlets as the life companies, also were granted broader investment outlets. In 1928 the New York State Banking Law was amended to permit investment in certain public utility bonds, and the field of eligible railroad obligations was broadened to include certain collateral trust bonds, equipment trust obligations, and terminal and tunnel bonds. ${ }^{3}$

The amendments alleviated the mild shortage of suitable investments. Life insurance companies domiciled in New York acquired a modest investment in preferred stocks during the remainder of 1928 and added to their holdings during I929. Companies subject in substance to the New York Law because they were doing business in New York State doubtless felt freer to invest in preferred stocks. The New York savings banks, accounting for about 50 per cent of the assets of all mutual savings banks, acquired utility bonds for the first time. But the broadened investment laws did not arrest the declining trend of yields. It is true that the depression materially reduced the assets of savings and loan associations, and the statistics of the Comptroller of the Currency indicate that a slight decline in savings bank assets also occurred in 1932 and 1933 . The assets of the life insurance companies, however, continued to increase, and on balance the flow of institutional funds into the investment markets, although it dwindled for awhile, never did terminate completely. Clearly only a substantial recovery in the private demand for capital funds could forestall a sharp decline in interest rates, and ultimately in the investment yields being realized by the savings institutions.

As we know, this recovery did not occur, at least in any volume, until I947. Investment yields continued to decline all during the r930's. In the meantime, it should be noted, the depression did not leave undamaged the portfolios of the savings institutions. A few institutions failed. Many more were occupied with the problems of a necessary financial reconstruction. Within a few years, however, many of these problems had responded to treatment or-because of the continued growth of institutional assets-had been reduced in relative significance, and the decline in investment yields became perhaps the top concern of institutional management. As the flow of savings into the institutions increased, the pressure upon investment officers mounted: They vied with each other in seeking new outlets for their money.

The disproportion between the flow of investment funds and the demand for capital, which lay at the roots of the discouraging yield trends, introduced important modifications in the investment activities of the savings institutions. In the first place, it was a factor toward encouraging the use of direct placements which now account for a large proportion of all the non-governmental bonds held by the life

'State of NEw York, Seventieth ANnul Report of the Superintendent of Insurance, Part I 56 (Legis. Doc. No. 33) (r929).

${ }^{8}$ N. Y. Laws r928, cc. $448,449$. 
insurance companies. With institutional lenders aggressively seeking outlets for their funds, the direct placement was a natural development. Direct negotiation, long the practice in the settlement of mortgage and most other loans, now established itself in the securities field. The general significance of this development is a subject in itself, more appropriate to other papers in the symposium.

In the second place, many state legislatures were encouraged to modify further the investment restrictions governing savings institutions. Most of these changes were in the life insurance laws. New York amended its law in $193^{8}$ to permit the investment of up to Io per cent of assets in housing developments, ${ }^{4}$ and again in 1946 to permit the investment of 3 per cent of assets in investment real estate. Finally, last spring the New York Law was amended once again, this time to permit investment in common stocks, subject to certain qualifications, of not more than 3 per cent of assets or one-third of surplus, whichever was less. ${ }^{6}$ The laws of many states have been amended to permit a proportion of assets, usually 5 per cent, to be invested at the discretion of the life insurance companies.?

In the third place, as pointed out earlier, most financial institutions were compelled for lack of suitable outlets in the private economy to place increasing amounts of United States Government bonds in their portfolios during the I930's and then to add to these even more substantially as a necessary measure of war finance. But when the war ended, there was good reason to liquidate these Government obligations and take advantage of the favorable opportunities developing in private sectors of the economy. The situation which thus developed was one in which the financial institutions could not escape criticism, whether they held or sold their Government obligations. If they held the bonds, the resulting shortage of funds would have been felt keenly in the private economy. This would have led to charges that the financial institutions were acting in concert to raise interest rates and were not playing their proper role in meeting the requirements of the economy for capital funds. If they sold the bonds, they created problems for the Treasury and the Federal Reserve Board, which were trying to maintain Government securities prices without monetizing the federal debt. Possessing no authority under the law to act in concert, and being in receipt of no direct official statement setting forth the wishes of monetary authorities, most institutions proceeded to dispose of their Government bonds as higher-yielding investments became available in the private economy. Thus, the decline of yields was halted two decades or more after it started. But the upturn has not been extensive and no one can say how long it will continue.

The commercial banks, like savings institutions, invested increasing amounts

"N. Y. Laws I938, c. $25 . \quad$ 'N. Y. Laws 1946, c. 509. $\quad$ 'N. Y. Laws 195r, c. 400.

7 A Report in Support of Proposed Amendments to Article 5, Section 81, of the New York InsUrance $\mathrm{LAW} 140$ Table I 8 (submitted to the Joint Committee on Insurance Rates and Regulation of the State of New York by the Life Insurance Association of America and the American Life Convention, January 30, 195I). 
during the rg20's in real estate loans and corporate securities, and no doubt they too felt the moderate decline in investment yields in these fields. However, the largest increase in commercial bank loans from I92I to I929 occurred in loans for carrying securities. Amounting to about 4 billion dollars in 1921, these loans (by member banks) appear to have increased to over ro billion dollars by the end of I929. The commercial banks found a ready answer to the problem of investment outlets in this vast and expanding market.

However, this outlet was not reliable. The stock market collapsed under the weight of speculation. Loans to carry securities then became unsuitable for commercial bank portfolios, and soon other forms of bank loans began to decline. The commercial banks began to buy United States Governments, and the yield trend of their investments commenced a sharp decline. The income stream, instead of being fed by the flow of loans into the private economy, began to be drained by repayments. Life insurance companies found themselves supplying funds, through policy loans and surrenders, for the purpose of liquidating bank loans.9

For a few years during the depression the commercial banks, like other institutional investors, were too concerned about the uncertain outlook for loans already on their books to worry very much about the contraction of investment outlets. After the bank holiday in 1933 , however, investment yields became a major concern of the commercial banks just as they did in the case of the savings institutions. Soon the commercial banks, like the insurance companies, began to make direct loans to business. A popular procedure was for a commercial bank to take short maturities, leaving long maturities of the same loan, or perhaps a loan senior to the bank loan, to the life insurance companies. Other outlets, such as personal loans and instalment credit, were explored in an effort to relieve the continuing decline in the trend of yields. These efforts, however, proved unavailing. Except for occasional interludes United States Government obligations continued to account for an increasing proportion of the commercial bank portfolios. 'The yield on investments declined to a low of 1.8 per cent, reached in 1944 and I945.

The upturn in investment yields of the commercial banks commenced in 1946 a little earlier than it did for the savings institutions. As indicated in Table 8, the banks, like the savings institutions, had an exceptionally large proportion of their assets invested in United States Governments when the war ended. Hence, the appearance of a strong demand for capital funds in the private economy encouraged the banks to seek higher investment yields by disposing of their United States Governments and investing the proceeds in business loans, real estate loans, and other forms of private credit. The commercial banks, however, are not merely in-

${ }^{8}$ See Banking and Monetary Statistics, Tables I9 and 22 (Board of Governots of the Federal Reserve System, Washington, D. C. I943). Comparable statistics do not seem to be available for the entire period.

- Proceedings of the Twenty-Stxty Annual Convention of the Association of Life Insurance Presidents 87 (I932). 
vestment institutions; they also furnish a large part of the nation's money supply. The shift in investment policy in I946, therefore, had broad economic consequences, leading ultimately to a major change in monetary and debt management policy of the Government. The circumstances leading up to this change call for a few comments at this point.

Unlike the savings institutions, when the commercial banks lend, they increase their deposits and therefore expand the nation's money supply. This process can continue as long as the banks possess the necessary reserves. But commercial bank reserves can be augmented by the sale of Government obligations to the Federal Reserve System and the System was committed at the end of the war to support the price of these obligations. It was recognized that the commercial banks could augment their reserves at will under these circumstances, and that the sale by nonbank holders of marketable debt which found its way into the Federal Reserve Banks also would increase commercial bank reserves. The debt management policy of the Treasury throughout the postwar period, therefore, has emphasized the retirement of marketable debt held by the banks, using for the purpose funds obtained from taxation and the sale of savings bonds to the non-bank public.

Prior to the outbreak of the Korean war the debt management policy of the Treasury and the investment policies of the commercial banks adjusted themselves to each other in a reasonably satisfactory manner. Indeed, from the end of 1946 through June 30, I950, the Treasury redeemed about 2I billion dollars of marketable debt, an amount well in excess of the 16 billion dollars of net disposals by the commercial banks and the principal savings institutions. ${ }^{10}$ The Federal Reserve, although supporting the price of United States Governments and hampered by a substantial inflow of gold, was able over this period to effect a reduction in its portfolios and thus to retain control of member bank reserves. Meantime, the member banks added about I.4 billion dollars to their capital and surplus. These funds, together with the proceeds of Government bond disposals and an increase in time deposits, permitted them to lend 13.7 billion dollars to the general public while increasing demand deposits by only 3.3 billion dollars. Thus, prior to the Korean war, the debt management program functioned with reasonable smoothness and on the whole it facilitated the investment programs of the commercial banks.

The outbreak of the Korean war upset the delicate monetary balance the Treasury and the Federal Reserve had maintained throughout most of the postwar period. The public, fearful of a new era of shortages, went on a buying spree, particularly in the durable goods and housing fields. Savings deposits were drawn down. Redemption of Series $E$ bonds exceeded sales. Increasing amounts of instalment credit and mortgage credit were sought from the financial institutions. The financial institutions in turn sought funds through the sale of Government obligations. Al-

\footnotetext{
${ }^{10}$ See Treasury survey of ownership of federal securities, Treasury Bulletin, March, 1947, p. 49, and id., September, 1950, p. 33.
} 
though the Treasury, benefiting from a tax rise, continued to redeem its marketable debt, it could not keep up with these sales. The bonds, therefore, backed up in the Federal Reserve portfolios and caused member bank reserves to increase. The Federal Reserve could no longer sterilize the inflationary effects of the bond support program. The necessary adjustment came with the well-known accord between the Treasury and the Federal Reserve last March, whereby rigid support of bond prices was abandoned in favor of a more flexible arrangement designed to maintain an orderly Government bond market.

\section{B. Operating Policy}

The declining trend of yields had important effects upon the operating as well as the investment policies of the financial institutions. In the life insurance field the effects were primarily on the actuarial side of the business. As the decline persisted, life insurance companies reluctantly reduced the dividend rate on outstanding policies and the rate of interest guaranteed in new policies. These actions tended, of course, to make life insurance more expensive to policyholders than otherwise would have been the case. Declining yields likewise required mutual savings banks to take a similar course of action-namely, to reduce the rate of interest paid on savings accounts.

In the commercial bank field resort was had to so-called "activity charges" on checking accounts and the sale of checks for small accounts. Beyond this, dividend payments to stockholders were drastically curtailed in the early I930's and while some improvement has occurred since the war the rates on most bank stocks are still comparatively low. This has placed bank stocks at a disadvantage with stocks of other enterprises and has made it difficult for banks to attract the capital needed to support the great wartime expansion in bank deposits.

\section{VI}

\section{SUMMARY}

This article has traced the trend of investment yields of major financial institutions during the past few decades and has considered some of the important implications of this trend. During the major part of the past few decades the investment yields of institutions have been declining due primarily to an inadequate demand for capital funds and an easy money policy by Government. All institutions have experienced an upturn in yields in the period following World War II due to the huge demand for corporate capital and mortgage funds.

The prolonged downward trend in yields had many important implications for financial institutions, both from the viewpoint of their investment policy and their general operating policy. All of the institutions were obliged to seek new outlets for their funds in higher-yielding investments, and this gradually required a loosening of state laws restricting institutional investments. The declining trend of yields tended to increase the net cost of life insurance and lowered the rate of return paid 
on savings deposits. It also reduced the dividends paid on commercial bank stocks and led to the introduction of service charges by the banks. Finally, it caused all financial institutions at the end of the war to look for higher-yielding replacements for a large proportion of their Government bond holdings, producing problems for the monetary authorities and leading ultimately to a change in monetary policy.

American economists have become accustomed to thinking of interest as a cost to society-a cost to taxpayers through interest on the public debt, a cost to home owners, a cost to corporate borrowers. A prime consideration of the Government's easy money policy has been to reduce the interest cost to society. Little attention has been paid until recently to interest as a source of income to society. Looked at in this light, reduced interest rates have penalized the millions of savers who are the ultimate owners of the assets of life insurance companies, savings banks, and other financial institutions. An appreciation of interest as a source of income as well as a cost to society may lead to a reconsideration of some of the factors that have been influential in guiding the Government towards an easy money policy. 